Published as:

Kofoed, J., \& Staksrud, E. 'We always torment different people, so by definition, we are no bullies': The problem of definitions in cyberbullying research. New Media \& Society, O(0), 1461444818810026. doi:10.1177/1461444818810026

\title{
We always torment different people, so by definition, we are no bullies': The problem of definitions in cyberbullying research
}

Corresponding Author: Elisabeth Staksrud, Department of media and communication, University of Oslo, Gaustadalleen 21, Blindern, 0317 Oslo, Norway. Email: elisabeth.staksrud@media.uio.no

\section{ABSTRACT:}

In this article, we investigate the power of prevailing definitions within the research field of cyberbullying. We address how these definitions, mostly deriving from developmental psychology, have had a problematic influence on the way researchers, policymakers, practitioners working with interventions, and children and young people themselves approach the challenge of understanding and preventing cyberbullying and its consequences. We analyse how the definition of cyberbullying stemming from developmental psychology is inadequate in addressing the complexities of technologically mediated exclusionary processes in educational- and peer-group settings. The dominant research paradigm has suppressed such complexity by deeming irrelevant the extensive experience with cyberbullying of many children and young people. Thus, we argue that it is necessary for the research field to refine definitional work. Research on cyberbullying needs to draw on a broad spectrum of empirical data and incorporate multiple and diverse theoretical perspectives.

Keywords Bullying, children, cyberbullying, definitions, education, ethical engagement, Internet, risk, victim, youth

\section{Introduction}

When children's and young people's experiences do not fit the definitions of cyberbullying often used by researchers, what kind of responsibility does the research community carry?

In this article, we investigate the power of prevailing definitions within the research field of cyberbullying. We address how these definitions, mostly deriving from developmental psychology, have had a problematic influence on the way researchers, policymakers, practitioners working with interventions, and children and young people themselves approach the challenge of understanding and preventing cyberbullying and its consequences. We analyse how the definition of cyberbullying is inadequate in addressing the complexities of technologically mediated exclusionary processes in educational- and peer-group settings. The dominant research paradigm has suppressed such complexity by deeming irrelevant the extensive experience with cyberbullying of many children and young people. Thus, we argue that it is necessary for the research field to open the definitions beyond the constraints of the developmental psychological definition coined by Dan Olweus. One way of opening the research paradigm is to listen to children and young people carefully and to refine definitional work. Research on cyberbullying 
needs to draw on a broad spectrum of empirical data and incorporate multiple and diverse theoretical perspectives.

We begin by addressing the dominant (Olweus-informed) definition of bullying. We then contrast this theoretical perspective with three observations originating from our own fieldwork. In line with other researchers (see, for instance, Canty et al., 2016; Ringrose and Rawlings, 2015), we identify how complexities of cyberbullying situations have been overlooked and how this is entangled with the prevailing research paradigm of bullying research. Furthermore, we highlight how some research on bullying seemingly forgets to genuinely listen to the children and young people it purports to protect. We pinpoint how listening can be a key driver in noticing how children and young people answer both questionnaires and fieldworkers differently than the definitions lead us to believe, and that their answers move beyond the boundaries of the research paradigm. By disregarding these voices, (too) much is left out, thus we argue that researchers bear a critical responsibility to adjust terminologies and definitions.

\section{Background and definitions}

Traditional definitions of bullying have centred on core traits such as repeated exposure, intentionality and asymmetric power relationships, perhaps best summarised by Dan Olweus (1994):

I define bullying or victimization in the following general way: A student is being bullied or victimized when he or she is exposed, repeatedly and over time, to negative actions on the part of one or more other students. It is a negative action when someone intentionally inflicts, or attempts to inflict, injury or discomfort upon another - basically what is implied in the definition of aggressive behavior (Olweus, 1973b).

Negative actions can be carried out by physical contact, by words, or in other ways, such as making faces or obscene gestures, and intentional exclusion from a group. In order to use the term bullying, there should also be an imbalance in strength (an asymmetric power relationship): the student who is exposed to the negative actions has difficulty in defending him/herself and is somewhat helpless against the student or students who harass. (p. 1173)

Schott points out how aggression and bullying have been entangled in definitional work. She explains this entanglement in terms of how 'the purpose of a definition is to place a specific phenomenon into a subset under a general category or concept' (Schott, 2013: 24). When Olweus places bullying as a subset of aggression, Schott (2013) argues, bullying will always be understood as a form of aggression (p. 24), thus confining the core of the problem to individual traits and behaviour. However, this subset approach can misguide us: '... the assumptions made about the general category become definitive for the specific phenomenon. For example, if bullying is a subset of aggressive behaviour, then bullies are aggressors' (Schott, 2013: 25). The argument in this article takes off from this vantage point.

For the past two decades, Olweus' definition of bullying has been used as the basis for much research and literature on cyberbullying 1 and has gained prominence not only within the field of bullying but also in cyberbullying research. Today, the most cited and popular models of cyberbullying stem from these psychological frameworks and definitions of traditional bullying (such as, but not limited to, Calvete et al., 2010; Hinduja and Patchin, 2012; Kowalski et al., 2014; Låftman et al., 2013; Olweus, 2012; Perren and Gutzwiller-Helfenfinger, 2012; Ybarra et al., 2012). This leads us to conclude that, even though this paradigm has been challenged in recent years, it stills holds a strong position. And, as argued by Canty et al. (2016), 
... consistent a priori application of this definition has created an aura of authority and temporal stability that obscures its origin and development, its disciplinary paradigm and assumption, and evidence that the term 'bullying' has multiple meanings and uses (Canty et al 2016: 48)

The tenet of the traditional definition, we argue, is the victim-perpetrator binary. Thus, this has become the core of much cyberbullying research.

To illustrate, we have examined a recent meta-analysis of cyberbullying research (Kowalski et al., 2014). Here, the general aggression model is highlighted as a useful theoretical framework from which to understand cyberbullying. The 131 studies included in Kowalski et al. have, to a large degree, the offline bullying definition(s) as a premise. We have combined the research foci and perspectives summarised in the meta-analysis into one figure, showing how they are interlinked. The terminology presented in the figure is harvested from the meta-analysis itself. As the figure shows, cyberbullying research has four main research foci - the bully, the victim, the bystander and the cyber-context. The bully-focus is typically found in research conducted from three angles: the nature and frequency of repeated aggression; a power imbalance perspective, where an imbalance with regard to technological skills and the concept of anonymity are at the core; and finally, outcomes for the bully. As for studies focusing on the victim, these predominantly focus on the victim's experience (or not) with traditional offline bullying, and on the short- and long-term outcomes for the victim. Short-term outcomes include psychological difficulties and dropping out of school while long-term consequences generally seem to focus on murder and suicide prevalence. As for bystanders, sometimes also referred to as audience, they are/it is in the cyberbullying context seen or defined as (potentially) infinite. Once again, the main research focus is on the outcome. For the bystander, this is typically linked to feelings of fear, and/or in-group belonging and enhancement. Finally, there is a group of studies where the cyber (or 'electric') context is studied, either in the form of how communication services are used (good or bad) or of the effects of different services on the individual.

The foci of the meta-analysis, represented in Figure 1, constitutes the backdrop for the following discussion of how cases from conducting surveys, doing fieldwork in schools and participating in policy work point at what is left out of cyberbullying research.

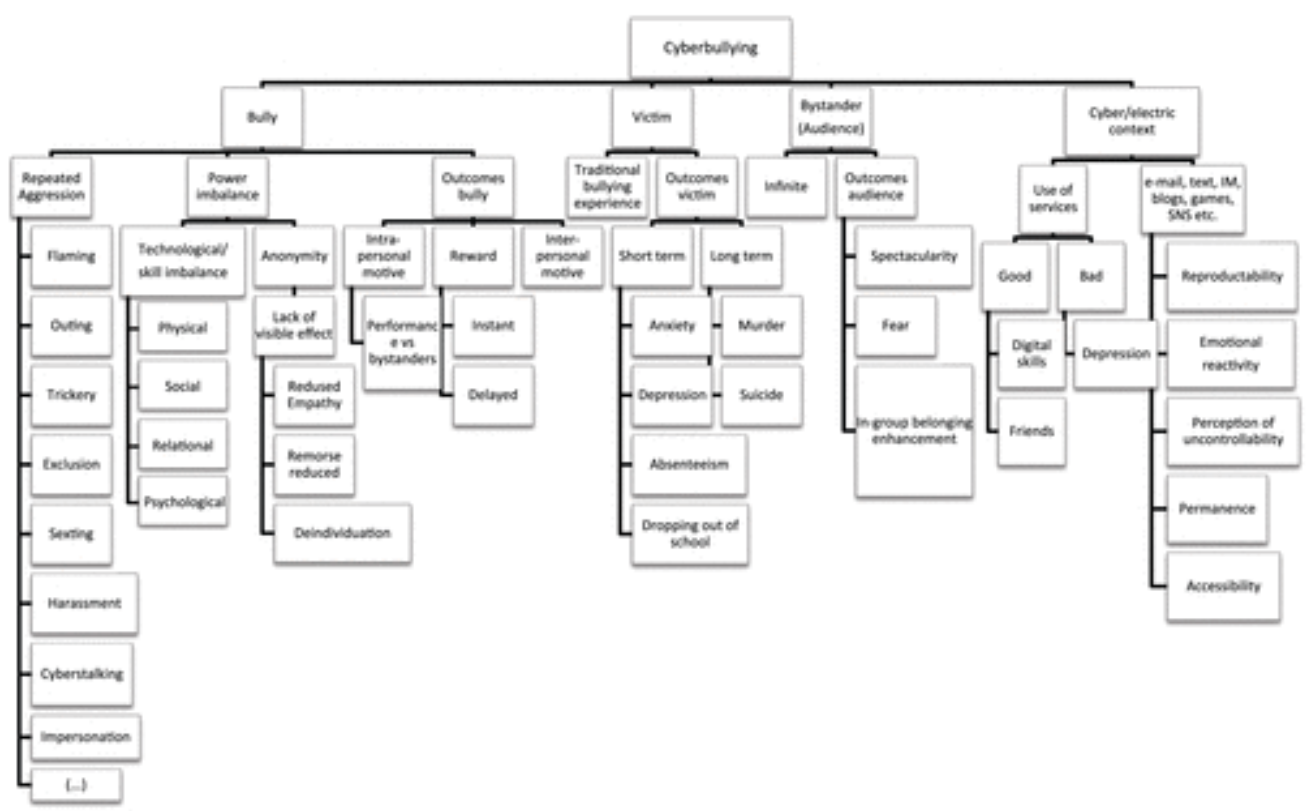


Figure 1. (Crude) overview of cyberbullying research focus and terminology (based on Kowalski et. al. 2014).

\section{Cases from cyberbullying research and policy fieldwork}

In a previous study, Ringrose and Rawlings (2015) demonstrate how cyberbullying practices should be considered in context with respect to the institutional and experiential realities of the young people at school where exclusion, violence and great distress can manifest in a variety of forms of 'ill-health' (p. 2). In the following, we present three cases drawn from such contexts. Our narratives of studying cyberbullying among children and young people, in Denmark and Norway, respectively, illustrate how their experiences with exclusionary practices mediated by technology cannot be fully grasped by the terminology of cyberbullying, and particularly not the core binary of bully and victim. Such experiences overspill, so to speak, the dominant terminology research and norms within cyberbullying research. Taken together, these narratives create a space for illustrating the dangers of an axiomatic use of the (Olweus-inspired) definition in cyberbullying research (Canty et al., 2016: 48) and the promises in listening to children and young people, as well as how such an enterprise of listening requires explicit ethics and methodologies.

\section{Case 1: Escaping the binary - experiences from qualitative research}

When first entering the field of cyberbullying research, I (researcher 1) read the conventional canon of literature on bullying. This taught me that bullying involves a victim, a perpetrator and a number of passive bystanders. I then visited schools to interview and observe children and young people engaged in what they themselves and/or their teachers recognised as cases of cyberbullying. When interviewing the first child, identified by her teachers as a victim of cyberbullying, her story seemingly followed a storyline which the research literature had led me to expect: she was the victim of cyberbullying by others. When interviewing the next child, who was allegedly involved in the same case of cyberbullying and identified by her teachers as 'the bully', however, her account did not fit the overall narrative. She did not present herself as the perpetrator; instead, she recounted being bullied herself. She included others who were not mentioned in the first interview as key figures, pointing out how other actors, other platforms and apps, other relationships, other temporalities and other spaces were involved. When interviewing the third, fourth, fifth and sixth students, further confusion arose, complexity prevailed and messiness reigned. Very little of the situation I encountered in school seemed to fit the pattern and definition of one bully and one perpetrator with an asymmetric power relationship. The children burst such dichotomies and I found myself asking, Did I not investigate a case of cyberbullying? Did the children involved misinterpret what cyberbullying was about? My doubts and hesitations led to a new question: Did cyberbullying perhaps come in other forms and shapes than the notion of a bully-victim dynamic?

\section{Case 2: Definitional overlearning in children - experiences from conducting surveys}

When researching the prevalence and nature of both traditional bullying and cyberbullying among children in Norway, I (researcher 2) have several times been confronted with what we will call 'definitional overlearning' in children who are asked to contribute. 
Norway has, for decades, institutionalised efforts to prevent bullying, both in the educational system, legal frameworks and educational practices. The importance of preventing bullying is broadly acknowledged, culminating in the 2015 government report 'To Belong' (NOU, 2015). The Norwegian Directorate for Education and Training gives financial support to schools wanting to implement anti-bullying programmes, such as the Olweus Bullying Programme (run by the Regional Centre for Child and Youth Mental Health and Child Welfare, Norway), PALS (developed by the Norwegian Centre for Child Behavioural Development), Zero and Respekt (developed by Erling Roland and the Centre for Learning Environment, University of Stavanger, Norway). All these programmes have been exported internationally and some of them commercialised. Anti-bullying is furthermore an integral part of the national curriculum for all Norwegian students from the first grade onwards. Similarly, school authorities and teachers are provided with and use checklists derived from academic definitions when considering whether or not a child has experienced bullying, something that would trigger legal obligations for the school to take action.

The emphasis on preventing bullying through intervention programmes intertwined with specific research parameters seems to have produced some puzzling side effects. I have repeatedly experienced how collecting data about cyberbullying via questionnaires when conducting research on other transgressive behaviour and topics has provoked an unexpected response from children and young people which I have never seen. Questionnaires on psychosocial aspects of the school environment, intended to map out children and young people's experiences with bullying and attempting to both establish its prevalence and tease out the complexities, are returned with scribbled messages from the 9- to 13-year-olds telling the researchers: 'You are defining it wrong', 'this is not how you are supposed to ask about bullying' and 'it has to be repetitive; bullying means repetitive', underlining key words and core understandings as to what defines cyberbullying, well-known from theoretical discussions. Children thus correct the questionnaires and express apparent confusion when asked questions outside the realm of what they have been trained to recognise as 'proper' bullying. For instance, an 8-year-old girl explicitly expressed her expectations towards the research focus and the researchers and described the confusion and bafflement she felt when she was not asked the 'standard' questions about bullying, but rather questions about friendship and positive experiences: 'At first I thought it was going to be about bullying and stuff, but it was only about friendship' (as quoted in Hordvei, 2014: 85).

Such corrective responses from students are encapsulated by one student fiercely disputing that he and his friends had cyberbullied a fellow student, not by claiming their innocence of any wrongdoing, but by citing Olweus' definition of bullying. He argued vehemently that they were not in violation of school regulations or national legislation as they, as he phrased it, '... always torment different people, so, by definition, we are no bullies'. Overlearning of definitions thus became not only a correction of researchers but hinted at how the power of definitions operate well beyond academic circles.

Case 3: ‘The inconsistent understanding of youth' - experiences from policy work

Our third case illustrates how the discrepancy between strong definitions of (cyber)bullying in research and (some) understandings of the phenomenon among children and young people is addressed in a recent policy document. In 2015, the ENABLE project, supported by the European Commission's Daphne programme and led by European Schoolnet, published its report on research on bullying in schools. In this report, their emphasis and summary of the field directly addresses the observed discrepancy between understandings of bullying among young people and definitions within research on the topic. However, surprisingly, the key to solving this dilemma, 
according to the report, is not for researchers to listen more carefully to children, but rather to teach the children the 'proper' definitions:

Research suggests that children and adolescents hold an inconsistent understanding of bullying, different from that of researchers. Investigating the sources of their beliefs and attitudes is crucial in altering them. ... Students who were given a definition of bullying reported being victimised less than students not provided with a definition. (ENABLE, 2015: 6)

The ENABLE report finds that there is a discrepancy between what takes place in schools and what existing definitions can capture. Yet, the recommendation is to fold the students' experiences into existing academic understandings by altering them. This will lower the reported prevalence of victimisation.

\section{Across the three cases}

Our experiences are puzzling. We see how key policy publications in policy and intervention work propose to teach children the 'right' definitions of victimisation. We also see how when conducting research with children and young people, they can resist definitions, pointing out how they do not fully grasp their experiences. And we see how everyday experiences with technologies, school life and peer groups overspills the basic tenets in the meta-analysis (see Figure 1).

We argue that traditional bullying definitions and the strong focus on prevalence of incidents of cyberbullying fail to grasp the subtleties and complexities in technologically mediated processes of inclusion and exclusion in schools and in peer groups. The three cases highlight what is not grasped by the hegemonic definition of cyberbullying and how research results can be used to manoeuvre apparently 'incorrect' responses. The messiness in cases of cyberbullying is omitted from much of the conceptual work and a substantial part of children's experiences with a vast range of exclusionary practices is thereby left out of the dominant research paradigm and, as a result, from operational and preventive work. Thus, the three cases beg the question, When children's experiences do not fit the definitions often used by researchers, what responsibility does the research community have?

We recognise how, for the past two decades, a substantial amount of survey research has provided further insights into the phenomenon of cyberbullying. Particularly, it has indicated the number of children who are involved in cyberbullying as perpetrators and victims, and how these numbers develop over time. Many of the surveys within the field are comparable to a certain degree (despite their methodological differences), with such comparisons providing additional valuable insights into the phenomenon. These are valuable insights. But what we experienced in the three cases is not touched upon. We recognise the conventional body of studies on bullying and cyberbullying (such as, but not limited to Hinduja and Patchin, 2010, 2012; Kowalski et al., 2014; Olweus, 1992; Smith, 2009; Smith and Steffgen, 2013), as well as the growing body of literature questioning psychological school bullying typologies, and particularly the binaries they produce (Canty et al., 2016; Ellwood and Davies, 2010; Horton, 2011; Kofoed and Ringrose, 2012; Kofoed and Stenner, 2017; Marwick and Boyd, 2014; Meyer, 2008; Patterson et al., 2015; Ringrose, 2008; Ringrose and Rawlings, 2015; Ringrose and Renold, 2010) which help us realise how 'overlearning' and 'overspilling' of experiential knowledge is not listened thoroughly to.

We also acknowledge that beyond the field of psychology, there are of course other disciplines offering different perspectives for the study of cyberbullying. Before dwelling on what is left out, let us shortly address how other disciplinary backgrounds have relevant perspectives to offer. 
Media studies, for example, is a source of research on the complexities of children's and students' online engagements, and generally refers to the online realm as a digital arena for digital activities (see, for instance, Buckingham, 2007; Buckingham and Willett, 2006; Byron, 2008; Drotner et al., 2008; Eastin and LaRose, 2000; Gasser et al., 2010; Hargittai, 2010; Hundley and Shyles, 2010; Kuipers, 2006; Livingstone, 2003; Livingstone and Helsper, 2010; Palfrey and Gasser, 2008; Staksrud, 2013; Tapscott, 1998). Here, cyberbullying is seen not only in relation to the definitions of bullying and cyberbullying derived from psychology but also in relation to other online risk experiences, as well as broader analytical frameworks that include several levels of analysis: individual, social, technical, cultural, legal, national (see, for instance, Livingstone et al., 2017). Within this line of thinking, cyberbullying is perceived differently. Such research provides insights into other aspects of online risk. A large body of research on online risks shows how risks and opportunities are interrelated (see, for instance, Livingstone, 2008; Livingstone and Haddon, 2009; Mascheroni et al., 2015), and how different types of online services and activities result in different levels and types of online risk exposure and engagements, including cyberbullying (such as Brandtzæg et al., 2009; Görzig and Frumkin, 2013; Görzig and Machackova, 2015; Livingstone et al., 2013; Staksrud et al., 2013). Jones et al. (2013) found that an increase in online harassment among US youth, from $6 \%$ in 2000 to $11 \%$ in 2010 , was likely attributable to changes in how young people were using the Internet. A study based on the 2010 EU Kids online survey with children (only 11- to 16-year-olds included, $\mathrm{n}=18,709$ ) found a correlation between cybervictimisation and visits to suicide websites (sites where people discuss how to kill themselves). Being a victim of cyberbullying increased the probability of visiting such sites by $134 \%$ (when controlled for age, gender, time spent online and psychological state), while being a victim of offline bullying showed no significant correlation (Staksrud and Ólafsson, 2016). As such, the definition of a power imbalance, where the victim has difficulties defending himself/herself, might not apply in situations where both (or all) parties feel bullied by one another. Other studies using the same dataset (a representative selection of 1000 children [9-16 years], and one of their parents, in each of the 25 participating European countries; Livingstone and Kids Online Research Network, 2011), found that, when confronted with online bullying or sexting, children with higher self-efficacy employ more proactive coping strategies, such as talking to someone or actively trying to solve the problem, finding that this helped the situation (D'Haenens et al., 2013). The study also found that both so-called cyberbullies and cyber victims are overrepresented in transgressive online activities, giving rise to new questions on the role of particular online services and affordances, regulatory measures, the normative digital climate and digital ecology. Moving into other disciplinary fields thus allow us to grasp other aspects of the phenomenon of cyberbullying differently.

Previous research has also shown how students' age influence their perceptions of what constitutes bullying, and that these perceptions differ from those of adults, such as teachers and parents (such as, but not limited to, Boulton et al., 2002; Craig et al., 2009; Eslea and Rees, 2001; Naylor et al., 2006; Smith and Levan, 1995). Such studies have informed how the mediation of communication influences bullying processes and experiences in ways not necessarily captured by the core premise of repeated, intentional aggression from someone in power against someone who is not. Insights from media studies and other research fields can thus inform and adjust the definitional work of cyberbullying originating from psychology.

The point is not that cyberbullying characterised by repetition and power imbalance does not exist, the point is that there is obviously 'more' to technologically mediated school and peer life than what can be captured in the traditional definition. We argue that resistance to what Canty et al. (2016) have called 'the axiomatic use of the definition in bullying research' (p. 48) needs to be taken into consideration. The resistance points to the overarching research regime's limitations, questioning its validity both implicitly and explicitly. 
Drawing on the three cases and the findings mentioned above from media studies, could it be, for instance, that both (or all) parties might experience victimisation, when involved in a digital turmoil of communication they cannot escape or resolve? Could it be that both (or all) parties, independent of the level of aggression, share vulnerabilities? Could it be that conflict escalation and resolutions vary with the distribution of vulnerabilities and victimisation that does not necessarily link with specific subjects? Could it be that the culture of the school is important in how cyberbullying is played out? Such questions merit further enquiry, but this is only possible if we accept that cyberbullying encompasses aspects that cannot be captured only by Olweus' definition of bullying.

Based on the cases outlined above, as well as the analysis outlined in Figure 1, we suggest that too many studies of cyberbullying are largely based on what Bronwyn Davies (2014) terms 'listening-as-usual': 'We listen in order to fit what we hear into what we already know' (p. 21). What we already know within the research field of cyberbullying seems to be the dominant definition mentioned earlier. In quantitative surveys, we often, and for good reason in terms of data comparability, ask questions in a manner we are used to, within the framework and binaries established in the Olweus-inspired research paradigm. However, in the cases presented above, children and young people suggest that we are not capturing the complexities of the phenomenon, something that creates new challenges when research findings translate into policy and preventive strategies. Listening to voices that overspill or contradict the knowledge which is taken to be hegemonic is an act of emergent listening (Davies, 2014: 21). Emergent listening is, she argues,

... not a simple extension of usual practices of listening. It involves working, to some extent, against oneself, and against those habitual practices through which one establishes 'this is who I am' [...] Emergent listening might begin with what is known, but is open to creatively evolving around something new. (Davies, 2014: 21)

Such acts and intensions of listening allow the three cases to surface as relevant and to include the fighting back and not-fitting-in-comments from the children and young people as relevant empirical information.

Research is at its core a quest for deeper insights into both new and known phenomena. We need to listen carefully and emergently to address questions such as: How do we know that our empirical data confirm that repetition and intentionality is at the core of cyberbullying? How do we know that the binary of victim-perpetrator still holds? How do we know if cyberbullying is an overrated phenomenon?

Through the scientific, ethical and legal regulation of responsibility, we as researchers are held accountable. Bullying research has become a fundamental tool for development of policy, regulation and preventive and protective measures, aiming to create 'good consequences' for children in general and victims and bullies in particular. Thus, it is critical that (cyber)bullying research allows for close scrutiny and continuous discussion of varied theoretical, methodological and definitional perspectives.

Such a scrutiny of concepts and definitions of course implies striking a delicate balance between, on one hand, knowing of the field, and on the other hand, enquiring into and hence accepting that there are aspects of children's lives of which we as scholars are (yet) unaware. If the aim is to grasp the changing nature of cyberbullying experiences, we need to listen emergently to children and not merely ask them questions we have asked before within frameworks and definitions developed well before the advent of social media. Listening emergently involves curiosity, allowing us to enquire into the unknown aspects of cyberbullying and entailing that we go beyond 
binaries, theories of positions and fixed academic disciplines. As such, emergent listening involves an interest in the many different experiences of cyberbullying that children and young people necessarily will have. Listening emergently entails an explicit obligation to ask children who have experiences with perpetration and/or victimisation, but also those who avoid the labels 'bully' or 'victim'. It entails asking the children who only know of or observe cyberbullying cases. This latter group includes both those who have been a friend of someone who has sent hurtful messages or pictures, shamed another student and those who acted as confidants of someone receiving unwanted pictures or messages, or those who unwillingly provide the content of such pictures and messages. Importantly, it also involves being curious about the positions, effects, experiences and consequences which we are yet unaware of.

Hence, the kind of research we encourage at the core of a child-centred methodology when investigating cyberbullying involves care and enquiry into something that one does not yet fully know or understand, into the unknown.

\section{Conclusion}

So, when children's and young people's experiences do not fit the definitions of cyberbullying often used by researchers, what kind of responsibility does the research community then carry?

Listening entails not just the act of emergent listening, during fieldwork and in actual conversations with children and young people. Listening also entails carefully observing and listening to our own research contributions and representations of young peoples' affective experiences, how they shape definitions, and how our analytical approach and the formats of questionnaires affect findings. Such a framework allows us as researchers to also follow the messiness and dramas of unorderly school life and peer interactions. We need to listen and to ask the difficult questions about school cultures, gender, media, privilege and opportunities. In doing so, it allows us to rethink cyberbullying, and to not forget that research definitions travel into politics and interventions.

\section{Acknowledgements}

The authors sincerely thank the anonymous reviewers for this article for their enthusiastic, thought provoking and diligent work. The authors would also like to thank Tijana Milosevic and Jørgen Kirksæther, both University of Oslo, and Kirsten Hvenegård-Lassen, Roskilde University, for comments on previous versions of this article.

\section{Funding}

The author(s) disclosed receipt of the following financial support for the research, authorship, and/or publication of this article: Jette Kofoed received funding for the fieldwork described in case 1 as part of the eXbus project, Exploring Bullying in Schools, by the TrygFonden (Denmark).

\section{Notes}

1.

While there are examples of alternative linguistic framing in English, including electronic bullying (Kowalski and Limber, 2007) and Internet bullying (Williams and Guerra, 2007), cyberbullying is by far the dominant English term, influencing definitional work. 


\section{References:}

Boulton, MJ, Trueman, M, Flemington, I (2002) Associations between secondary school pupils' definitions of bullying, attitudes towards bullying, and tendencies to engage in bullying: age and sex differences. Educational Studies 28: 353-370.

Brandtzæg, PB, Staksrud, E, Hagen, I. (2009) Norwegian children's experiences of cyberbullying when using different technological platforms. Journal of Children and Media 3: 349-365.

Buckingham, D (2007) Youth, Identity, and Digital Media. Cambridge, MA: MIT Press.

Buckingham, D, Willett, R (2006) Digital Generations: Children, Young People, and the New Media. Mahwah, NJ: Lawrence Erlbaum.

Byron, T (2008) Safer Children in a Digital World: The Report of the Byron Review. London: Department for Children, Schools and Families and Department for Culture, Media and Sport.

Calvete, E, Orue, I, Estévez, A. (2010) Cyberbullying in adolescents: modalities and aggressors' profile. Computers in Human Behavior 26: 1128-1135.

Canty, J, Stubbe, M, Steers, D. (2016) The trouble with bullying - deconstructing the conventional definition of bullying for a child-centred investigation into children's use of social media. Children \& Society 30: 48-58.

Craig, W, Harel-Frisch, Y, Fogel-Grinvald, H. (2009) A cross-national profile of bullying and victimization among adolescents in 40 countries. International Journal of Public Health 54: $216-224$.

Davies, B (2014) Listenting to Children: Being and Becoming. London: Routledge.

D’Haenens, L, Vandoninck, S, Donoso, V (2013) How to Cope and Build Online Resilience? London: EU Kids Online, London School of Economics and Political Science. Available at: http://eprints.lse.ac.uk//48115

Drotner, K, Siggaard Jensen, H, Schrøder, KC (2008) Informal Learning and Digital Media. Newcastle: Cambridge Scholars Publishing.

Eastin, MS, LaRose, R (2000) Internet self-efficacy and the psychology of the digital divide. Journal of Computer-Mediated Communication 6. Available at: https://onlinelibrary.wiley.com/doi/10.1111/j.1083-6101.2000.tb00110.x

Ellwood, C, Davies, B (2010) Violence and the moral order in contemporary schooling: a discursive analysis. Qualitative Research in Psychology 7: 85-98.

ENABLE (2015) Bullying in Schools: A Summary of Research and Anti-Bullying Initiatives. Brussels: European Schoolnet, p. 36.

Eslea, M, Rees, J (2001) At what age are children most likely to be bullied at school? Aggressive Behavior 27: 419-429. 
Gasser, U, Maclay, C, Palfrey, J (2010) Working Towards a Deeper Understanding of Digital Safety for Children and Young People in Developing Nations. Cambridge, MA: The Berkman Center for Internet \& Society, Harvard University.

Görzig, A, Frumkin, L (2013) Cyberbullying experiences on-the-go: when social media can become distressing. Cyberpsychology: Journal of Psychosocial Research on Cyberspace 7: 4.

Görzig, A, Machackova, H (2015) Cyberbullying from a socio-ecological perspective: a contemporary synthesis of findings from EU Kids Online. In: Cammaerts, B, Anstead, N, Garland, R (eds) MEDIA@LSE Working Paper Series. London: Media@LSE, Department of Media and Communications, London School of Economics and Political Science.

Hargittai, E (2010) Digital na(t)ives? Variation in internet skills and uses among members of the 'net generation'. Sociological Inquiry 80: 92-113.

Hinduja, S, Patchin, JW (2010) Bullying, cyberbullying, and suicide. Archives of Suicide Research 14: 206-221.

Hinduja, S, Patchin, JW (2012) Cyberbullying: neither an epidemic nor a rarity. European Journal of Developmental Psychology 9: 539-543.

Hordvei, SM (2014) 'Jeg trodde først det skulle handle om mobbing og sånn, men så var det jo bare vennskap' - En studie av holdningskampanjen Blime, og NRKs rolle som verdiformidler. Master's Thesis, Institutt for medier og kommunikasjon, Universitetet i Oslo, Oslo.

Horton, P (2011) School bullying and social and moral orders. Children \& Society 25: 268277.

Hundley, HL, Shyles, L (2010) US teenagers' perceptions and awareness of digital technology: a focus group approach. New Media \& Society 12: 417-433.

Jones, LM, Mitchell, KJ, Finkelhor, D (2013) Online harassment in context: trends from three youth internet safety surveys (2000, 2005, 2010). Psychology of Violence 3: 53-69.

Kofoed, J, Ringrose, J (2012) Travelling and sticky affects: exploring teens and sexualized cyberbullying through a Butlerian-Deleuzian-Guattarian lens. Discourse: Studies in the Cultural Politics of Education 33: 5-20.

Kofoed, J, Stenner, P (2017) Suspended liminality: vacillating affects in cyberbullying/research. Theory \& Psychology 27: 167-182.

Kowalski, RM, Limber, SP (2007) Electronic Bullying among Middle School Students. Journal of Adolescent Health 41: S22-S30. Available at: https://doi.org/10.1016/j.jadohealth.2007.08.017

Kowalski, RM, Giumetti, GW, Schroeder, AN. (2014) Bullying in the digital age: a critical review and meta-analysis of cyberbullying research among youth. Psychological Bulletin 140: 1073-1137.

Kuipers, G (2006) The social construction of digital danger: debating, defusing and inflating the moral dangers of online humor and pornography in the Netherlands and the United States. New Media \& Society 8: 379-400. 
Låftman, SB, Modin, B, Östberg, V (2013) Cyberbullying and subjective health: a largescale study of students in Stockholm, Sweden. Children and Youth Services Review 35: 112-119.

Livingstone, S (2003) Children's use of the internet: reflections on the emerging research agenda. New Media \& Society 5: 147-166.

Livingstone, S (2008) Taking risky opportunities in youthful content creation: teenagers' use of social networking sites for intimacy, privacy and self-expression. New Media \& Society 10(3): 393-411.

Livingstone, S, Haddon, L (2009) Kids Online: Opportunities and Risks for Children. Bristol: The Policy Press.

Livingstone, S, Helsper, E (2010) Balancing opportunities and risks in teenagers' use of the internet: the role of online skills and internet self-efficacy. New Media \& Society 12: 309-329.

Livingstone, S and Kids Online Research Network EU (2011) EU Kids Online: Enhancing Knowledge Regarding European Children's Use, Risk and Safety Online, 2010 (Data Collection, SN: 6885). Colchester: UK Data Service.

Livingstone, S, Mascheroni, G, Staksrud, E (2017) European research on children's internet use: assessing the past and anticipating the future. New Media \& Society 20(3): 11031122.

Livingstone, S, Ólafsson, K, Staksrud, E (2013) Risky social networking practices among 'underage' users: lessons for evidence-based policy. Journal of Computer-Mediated Communication 18: 303-320.

Marwick, A, Boyd, D (2014) 'It's just drama': teen perspectives on conflict and aggression in a networked era. Journal of Youth Studies 17: 1187-1204.

Mascheroni, G, Vincent, J, Jimenez, E (2015) 'Girls are addicted to likes so they post seminaked selfies': peer mediation, normativity and the construction of identity online. Cyberpsychology: Journal of Psychosocial Research on Cyberspace 9: 5.

Meyer, EJ (2008) A feminist reframing of bullying and harassment: transforming schools through critical pedagogy. Revue des sciences de l'éducation de McGill 43: 33-48.

Naylor, P, Cowie, H, Cossin, F. (2006) Teachers' and pupils' definitions of bullying. British Journal of Educational Psychology 76: 553-576.

NOU (2015) A høre til - Virkemidler for et trygt psykososialt skolemiljø. Oslo: Kunnskapsdepartementet, p. 448.

Olweus, D (1992) Mobbing i skolen - Hva vi vet og hva vi kan gjøre. Oslo: Universitetsforlaget.

Olweus, D (1994) Bullying at school: basic facts and effects of a school based intervention program. Journal of Child Psychology and Psychiatry 35: 1171-1190.

Olweus, D (2012) Cyberbullying: an overrated phenomenon? (Invited expert discussion paper). European Journal of Developmental Psychology 9: 520-538.

Palfrey, J, Gasser, U (2008) Born Digital: Understanding the First Generation of Digital Natives. New York: Basic Books. 
Patterson, LJ, Allan, A, Cross, D (2015) Adolescent perceptions of bystanders' responses to cyberbullying. New Media \& Society 19(3): 366-383.

Perren, S, Gutzwiller-Helfenfinger, E (2012) Cyberbullying and traditional bullying in adolescence: differential roles of moral disengagement, moral emotions, and moral values. European Journal of Developmental Psychology 9: 195-209.

Ringrose, J (2008) 'Just be friends': exposing the limits of educational bully discourses for understanding teen girls' heterosexualized friendships and conflicts. British Journal of Sociology of Education 29: 509-522.

Ringrose, J, Rawlings, V (2015) Posthuman performativity, gender and 'school bullying': exploring the material-discursive intra-actions of skirts, hair, sluts, and poofs. Confero: Essays on Education, Philosophy and Politics 3: 80-119.

Ringrose, J, Renold, E (2010) Normative cruelties and gender deviants: the performative effects of bully discourses for girls and boys in school. British Educational Research Journal 36: $573-596$.

Schott, RM (2013) The social concept of bullying: philosophical reflections on definitions. In: Schott, RM, Søndergaard, DM (eds) School Bullying: New Theories in Context. Cambridge: Cambridge University Press, pp. 21-46.

Smith, PK (2009) Cyberbullying: abusive relationships in cyberspace. Journal of Psychology/Zeitschrift für Psychologie 217: 180-181.

Smith, PK, Levan, S (1995) Perceptions and experiences of bullying in younger pupils. British Journal of Educational Psychology 65: 489-500.

Smith, PK, Steffgen, G (2013) Cyberbullying through the New Media: Findings from an International Network. New York: Psychology Press.

Staksrud, E (2013) Digital Mobbing: Hvem Hvor, Hvordan, Hvorfor - og hva kan voksne gjøre? Oslo: Kommuneforlaget.

Staksrud, E, Ólafsson, K (2016) Hva kjennetegner europeiske barn som har erfaring med nettsider hvor folk diskuterer måter å ta sitt eget liv på? Suicidologi 21: 36-43.

Staksrud, E, Ólafsson, K, Livingstone, S (2013) Does the use of social networking sites increase children's risk of harm? Computers in Human Behavior 29: 40-50.

Tapscott, D (1998) Growing Up Digital: The Rise of the Net Generation. New York: McGraw-Hill.

Williams, KR, Guerra, NG (2007) Prevalence and predictors of internet bullying. J Adolesc Health 41(6 Suppl 1): S14-21. DOI: 10.1016/j.jadohealth.2007.08.018

Ybarra, ML, Boyd, D, Korchmaros, JD. (2012) Defining and measuring cyberbullying within the larger context of bullying victimization. Journal of Adolescent Health 51: 53-58.

Google Scholar | Medline | ISI 
Jette Kofoed is an associate professor of Social Psychology at Aarhus University, Denmark. Her research focuses on cyberbullying, young people, social media, and particularly on the affectivity of extreme on-line exclusions, such as cyberbullying. She specializes in qualitative methodologies and research ethics and is currently undertaking research of photo-elicitation practices among young people (Snapchat and Instagram) with particular focus on ephemerality and intimacy.

Elisabeth Staksrud, PhD, is a professor at the Department of Media and Communication, University of Oslo. Her main research interests evolves around 1) Children and online risk and opportunities, including rights-based issues and transgressive online behaviour; 2) Freedom of expression and censorship, with a particular interest in new media and regulatory legitimacy; 3 ) Research ethics. 